\title{
Decentralization and Financial Local Governments Performance: How Does Fiscal Autonomy Affect Spending, Economic Growth, and Poverty in East Java Indonesia?
}

\author{
Risqi Noor Hidayati Putri* Susilo Putu Mahardika Adi Saputra \\ Department of Economics, Faculty of Economics and Business, University of Brawijaya, Indonesia
}

\begin{abstract}
Generally, fiscal policy is implemented through tax instruments (T) and governmental spending $(G)$. This research aims at investigating and analysing the impact of the implementation of fiscal decentralization on the local economic growth and poverty in East Java. This study uses panel data across regencies and cities of East Java Province in the period of 2010-2015, and employs Path Analysis to directly and indirectly identify the effect of local financial performance on economic growth and poverty. The results indicate that there is a significant effect of local financial performance on economic growth and poverty with different directional relation. Furthermore, fiscal policy in Indonesia is designed within the framework of pro growth and pro poor, but the limitations of fiscal room and high inequality become obstacles. Using the pro poor growth index (PPGI) approach, the results show that economic growth benefits the poor at different levels in each regencies and cities.
\end{abstract}

Keywords: Local financial performance, capital expenditure, economic growth, poverty, inequality, pro poor growth

DOI: $10.7176 / \mathrm{JPID} / 51-04$

Publication date: November $30^{\text {th }} 2019$

\section{Introduction}

Fiscal decentralisation refers to the transfer of authority for public spending and revenue collection from national to subnational governments. Fiscal decentralization can lead to better resources allocation and a more productive and possibly smaller public sector. Barzelay (1991) support this perception by mentioning the primary mission of fiscal decentralization is to create efficiency and effectiveness in the management of regional resources, improve the quality of public services and the welfare of society and created a space for people to participate in the development process. Tanzi (1995) and Ter-Minassian (1997) have argued that fiscal decentralisation can facilitate the development of appropriate macroeconomic policies in general and it can also help in implementation of stabilization policies in particular. Thus, the purpose of the creation aspects of the region's autonomy will be realized as well as support the accelerated development of the national economy.

The main feature of an autonomous region to be able to implement its regional autonomy lies in the fiscal capacity of the region, that is, an autonomous region must have the authority and capacity to explore its own financial resources, and to manage the finances sufficiently for governing its region. Musgrave (1959) and Oates (1972) developed the fiscal federalism theory that emphasizes the importance of revenue and expenditure assignment among government levels to improve the societal welfare.

The government has the functions of allocation, distribution, and stabilization inherent to the fiscal instrument. Therefore, the fiscal policy embodied in APBD can be utilized to encourage growth (pro growth) and simultaneously to distribute the results of growth into all social levels (pro poor). Increasing local taxes to build up the regional fiscal capacity has a potential to increase local spending which can further directly increase the regional output.

Furthermore, Keynes's theory of three-sector economy mentioned that consumption, investment, and governmental spending affect economic growth in a region. In the endogenous growth model developed by Barro (1990), it was stated that productive spending by government (infrastructure, education, health) financed by taxes is an engine of long term economic growth.

One of the succes of fiscal instrument is the availability of sufficient and flexible fiscal opportunity. Currently the government has limited fiscal scope due to the low fiscal capacity, while the fiscal needs are high. One of the needs is that the government has an increasing liability for expenditures. This condition makes the government keep seeking sources for local revenue. Through budget, the government functions as a provider of public goods and services. The budget as a policy instrument should contain performance, both for internal assessment and for linkages to promote economic growth which will further reduce poverty. The performance associated with the budget is the financial performance in the form of a comparison between the components contained in the budget (Halim, 2008).

Regional economic development is a process wherein the Local Government and its people manage the existing resources and form a partnership between the Local Government and the private sectors to stimulate creating job opportunities and developing economic activities (Arsyad, 1999 and Blakely, 1989 in Kuncoro 2014). 
The progress of regional economic development can be seen on the high economic growth. One of the factors affecting economic growth is the investments made by local governments. The indicator for the number of regional investment can be seen through the ratio of capital expenditure towards total expenditure in the Local Revenue and Expenditure Budget (APBD). In order to increase investment, local financial capacity must be adequate. In addition, the allocation of capital expenditure on local governments is also influenced by the local financial performance. Thus, there is a relation between regional economic growth and the allocation of capital expenditure as well as financial performance. Economic growth in a country according to Zhang and Zho (1998) can be influenced by several factors, such as fiscal decentralization, labor, national and provincial taxation, investment, economic accessibility, and governmental spending in each sector of economy.

Furthermore, the level of poverty also becomes one factor of economic development. Based on the vicious circle of poverty theory proposed by Nurkse in Kuncoro (2006), market imperfection and lack of capital lead to low productivity. Low productivity results in low income, further it implicates on low savings and investment. The low investment makes the existing capital be limited and this condition will repeat if it is not solved immediately. And then, some opinions stated that efforts to achieve growth and equity cannot be realized at the same time. Inequality is the opportunity cost that must be endured if a region wants an economic growth (Krongkaew \& Kakwani, 2003). On the other hand, redistribution of income causes inefficient economy. Consequently, the government can only prioritize the developmental goals.

A number of studies have been conducted to examine the effects of fiscal decentralization and local financial performance on economic growth and poverty (Slavinskaite, 2017, Yang, 2016; Lisna et al., 2013; Nguyen, 2011; and Sularso, 2011; Barro, 1990). Meanwhile, a number of studies are interested to observe the influence of fiscal policy on economic growth, poverty and inequality (Piotrowska, 2016; Farwati, 2013; Shin, 2012; Qiao et.al, 2008; Son and Kakwani, 2007; Bourguignon, 2004).

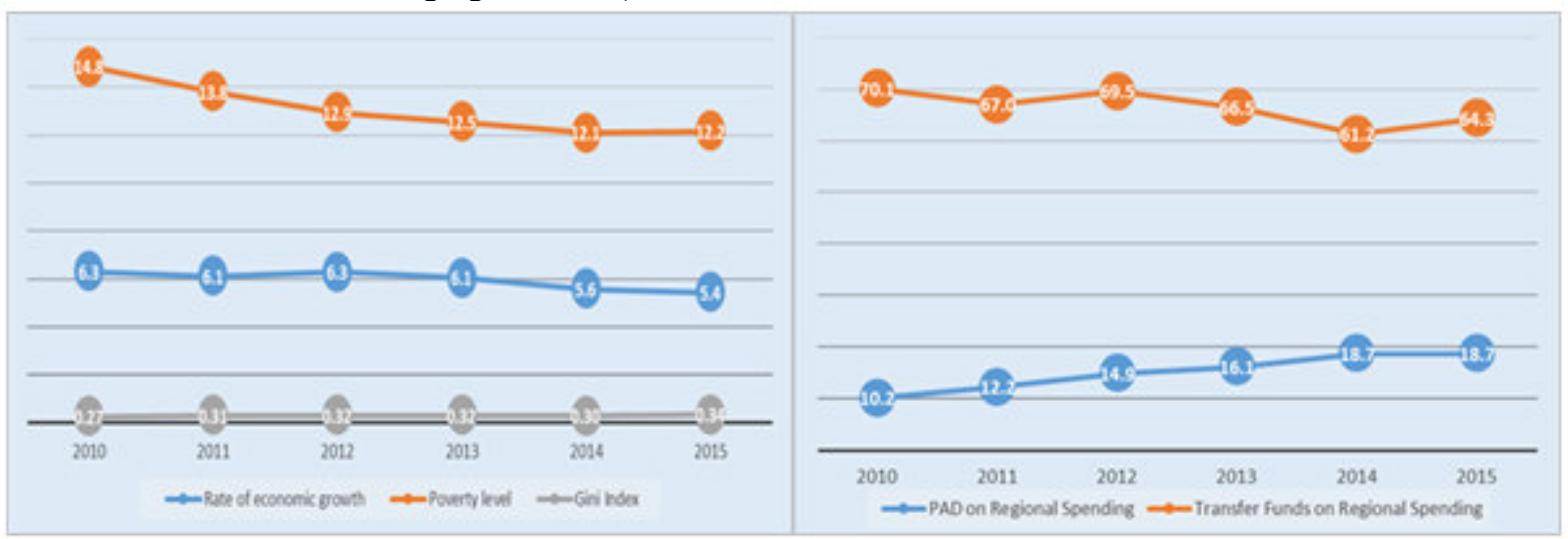

Figure 1. Regional Independence, Regional Dependence, Economic Growth, Poverty, and

Gini Index in East Java Province 2010-2015 (\%)

In line with the spirit of decentralization, one of the provinces that are very interested in the implementation of fiscal decentralization is the province of East Java. East Java has largest autonomous region in Indonesia, but there are some differences between the characteristics of the region and its various problems. East Java has a strategic role as the second-largest contributor to national GDP after DKI Jakarta and has rate of GRDP above the national GDP rate. The average growth rate in East Java from 2010 to 2015 was $6 \%$ (in Figure 1). The growth rate decreased to $0.7 \%$ in 2013 until 2015 with the effects of world economic crises on the economy. The relative poverty in East Java was $14.8 \%$ in 2010 . Figure 1 show these poverty rates that decreased, the head count index (P0) is $14.8 \%$ in 2010 , it is decreased to $12.2 \%$ in 2015 . Moreover, the coefficient of variation index increased from 0.27 to 0.34 in 2015. World Bank inequality of income indicators also showed similar results where the distribution of top $20 \%$ population expenditure increased from $42.55 \%$ to $48.87 \%$, while the distribution of group expenditure $40 \%$ of the lowest population decline from $20.81 \%$ to $16.61 \%$. However, most of the regencies and cities governments of East Java still experience fiscal dependency and have low capital expenditure allocations with varying distributions in each region. On average, the regency and city revenue sources in East Java are still dominated by transfer funds rather than PAD. Meanwhile, the ratio of capital expenditure towards total spending of East Java is the second-lowest spending after Central Java, that is $8.2 \%$; it is far below the national average of $20.3 \%$.

The background of problems in this research is the various views on the role of fiscal decentralization and the concept of pro poor growth towards inclusive development. Based on the description above, the concept of fiscal decentralization through local financial performance becomes important as a form of government intervention to increase economic growth and to reduce poverty, while pro poor growth is as an important concept to detect patterns of economic growth, poverty and inequality. Thus, the government needs the right combination 
of policies to solve poverty problem through the acceleration of economic growth and the optimization of the use of resources through local financial performance.

\section{Literature Review and Research Framework}

Fiscal decentralization is an urgent necessity to consider aspects such as: (1) an embodiment of the function and role of the modern state that more emphasis to promote the general welfare (welfare state); (2) the presence of regional autonomy can also be approached from a political perspective in which the country become an organization of power in which there are the corridors of power at both the superstructure and infrastructure tend to abuse authority so decentralization is expected to prevent it; (3) from the perspective of modern government management of the fiscal decentralization is the embodiment of the demands of efficiency and effectiveness of services to the community in order to realize common prosperity (Bird and Vaillancourt, 2000).

The government functions as the provider of public goods and services, while the budget is as a tool for developmental planning and a standard measure for performance evaluation. One measure that can be used to see how big the role of decentralization of post-regional autonomy from the fiscal side is by measuring local financial performance. Financial performance is a measure of performance using the financial indicators to assess performance by conducting various analyses to obtain a financial position representing the reality of entity and the performance potentials that will continue. According to Halim (2008) analysis of financial performance is an attempt to identify financial features based on available financial statements.

The fiscal federalism theory suggests that economic growth will be achieved through fiscal decentralization. With fiscal decentralization, each region is authorized by the central government to explore its financial resources to finance the needs of the region, not only the daily needs of the local government but also the capital expenditure needs. Classical theory of growth states that the economic growth of a region can be influenced by four factors, among others: population, technology, natural resources and capital. The linkage between local revenue and regional expenditure can also be an incentive for local governments to improve regional economies (government expenditure theory and new perspective theories).

Figure 2 explained that after the reformation 1998, the policy of regional autonomy began since the issuance of Laws 22 on Regional Government which has been revised by the Act No. 23 of 2014 and 25 of 1999 on Financial Balance between Central and Local Government were also revised by the Act No. 33 of 2004 where the regions were granted the authority in the form of political, administrative, economic and fiscal decentralization. Fiscal decentralisation refers to the transfer of authority for public spending and revenue collection from national to subnational governments. The allocation of financial resources to each level of government is important for two main reasons. First, it would enable each level of government to exercise constitutionally assigned legislative and executive responsibilities. Second, taxing powers and expenditure are important policy instruments for the three objectives of macroeconomic policy - maintaining economic stability, pursuing high economic growth, and equity (Nasution, 2016).

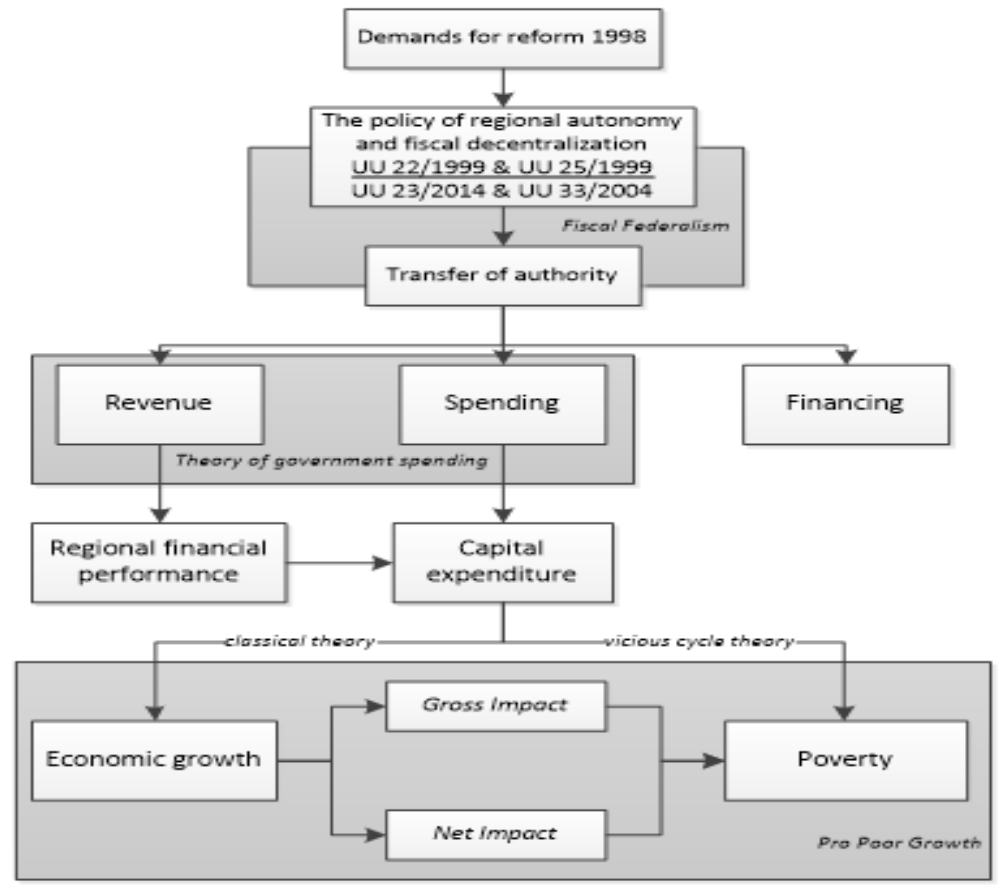

Figure 2. Research Framework

Source: illustration of the author 
Quoting Lin and Liu (2000), economic growth can occur in two ways: firstly, increasing capital investment and secondly, doing efficiency in the resources. Regional capital expenditure has a high multiplier effect on the increase of GRDP because capital expenditure can be used for supplying public goods at local level such as road and bridge infrastructure, traditional market buildings, stations, drainage systems, irrigation channels and other physical capitals. The provision of such public goods will further encourage the economic activity of the private and household sectors. It proves that regional capital expenditures are very effective for encouraging GRDP. It is also in accordance with Barro (1990) and Kuncoro (2004) suggesting that local governmental spending for public investment or public infrastructure has a positive effect on the output of goods and services.

Based on the vicious cycle theory, one of the main causes of poverty is due to the low capital access on development. In line with Friedman's (Kuncoro, 2006) argument it is stated that poverty occurs due to the inequality of opportunity to accumulate a basis of social power, wherein it consists of productive capital or assets and financial resources. In the process to improve society welfare, the local governments are always encouraged to increase the allocation of capital expenditure in APBD. In addition, the development of economic infrastructure will encourage widespread economic activities which are expected to invite private investment, thereby increasing the production capacity of goods and services in various economic activities of the society which will further reduce the regional poverty level.

The importance of economic growth for poverty alleviation has become a major concern in the researches (Deininger and Square, 1996, Dollar and Kraay, 2002). These researches suggest a positive correlation between poverty alleviation and economic growth estimating growth elasticity of poverty. Bourguignon (2003) discuss the growth elasticity of poverty explaining the heterogeneity across countries and adding the role of income redistribution in poverty reduction. The pro-poor growth concept becomes under the interest as following of the poverty reduction objectives of economic development. The basic of pro-poor researches is about how economic growth affects poor, how economic growth's benefits are distributed and how much poor profit from these benefits (Ravallion, 2004; Kakwani and Son, 2008; Klasen, 2008; Son and Kakwani, 2008). Pro-poor growth is a reciprocal relationship among three elements: growth, poverty, and inequality. Poverty levels are not only influenced by economic growth but also affected by the levels and changes in inequality of income distribution.

\section{Research Methodology}

This study used secondary data from the Ministry of Finance and the Central Bureau of Statistics in the form of panel data of 29 regencies and 9 cities in East Java. The data were analyzed using path analysis. The main objective of this research is to directly examine the influence of financial performance on economic growth and poverty, and to indirectly test the influence of financial performance on economic growth and poverty level through capital expenditure. Measured the level of fiscal decentralization of financial performance as (1) ratio of local revenue to total regional income; (2) ratio of transfer funds to regional income; (3) ratio of local revenue to transfer funds; (4) target to regional revenue realization; (5) regional income growth; and (6) tax effort.

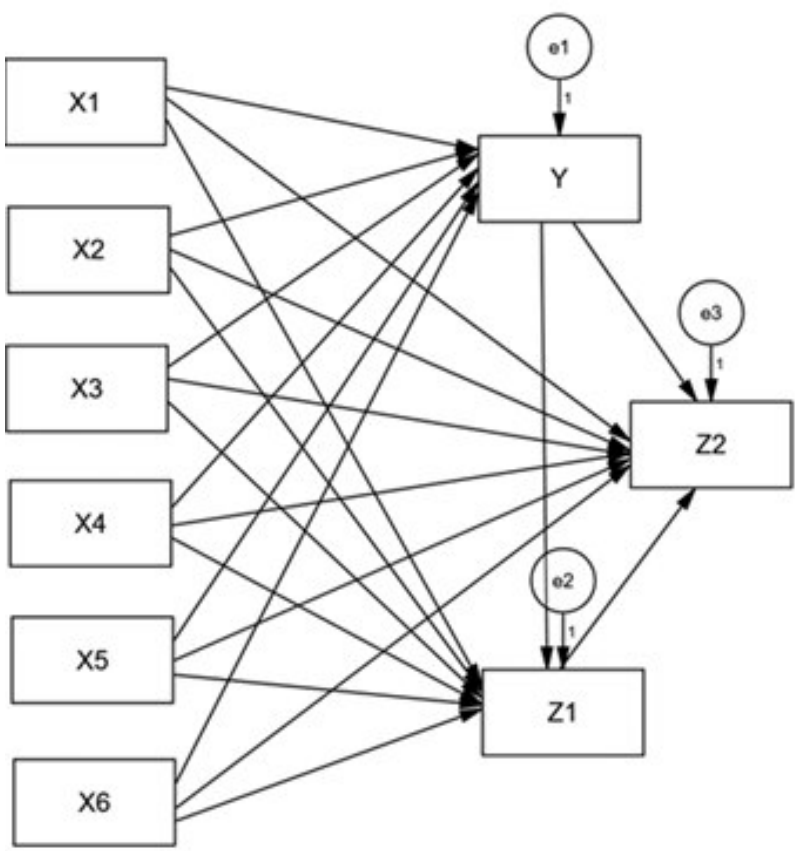

Information:

X1 : Degree of Fiscal Decentralization (RDDF)

$\mathrm{X} 2$ : Local Financial Independence (RKED)

$\mathrm{X} 3$ : Dependence of Local Finance (RKKD)

X4 : Tax Effort (DP)

X5 : Growth of PAD (RPAD)

X6 : Local Revenue Effectiveness (REPD)

$\mathrm{Y}$ : Capital Expenditure (BM)

Z1 : Economic Growth (PE)

Z2 : Poverty Level (TK)

Figure 3. Operational Path Diagram Model 
To answer the formulation of the next problem, that is to know in which category level of economic growth side alignment at society at district and city level. For the pro poor growth index, we used the Pro Poor Growth Index (PPGI) model developed by Kakwani and Pernia (2000) as shown in the following equation:

$P P G I(Ø)=\frac{\text { Net Impacts of Growth to Poverty }}{\text { Gross Impacts of Growth to Poverty }}$

The net effect of growth on poverty can be estimated by the following equation:

$\log \mathrm{Pkt}=\varphi+\lambda \log \mathrm{Wkt}+\varepsilon \mathrm{kt}$

The gross effect (GDP) can be estimated through the following equation:

$\log \mathrm{Pkt}=\omega+\gamma \log \mathrm{Wkt}+\delta \log \mathrm{Gkt}+\varepsilon \mathrm{kt}$

Where Pkt is poverty level in area $\mathrm{k}$ in period $\mathrm{t} ; \Lambda$ is net elasticity of economic growth to poverty; Wkt is economic growth in region $\mathrm{k}$ in period $\mathrm{t} ; \mathrm{\gamma}$ is gross economic growth elasticity of poverty; and Gkt is gini coefficient for region $\mathrm{k}$ in period $\mathrm{t}$. The identification of PPGI divided into five, i.e. if $1.0<\varnothing$ it is categorized as strong pro poor; if $0,66<\varnothing \leq 1,0$ is categorized as pro poor; if $0.33<\varnothing \leq 0,66$ it is categorized as moderat pro poor; if $0<\varnothing \leq 0,33$ it is categorized as weak pro poor; and if $\varnothing \leq 0$ it is categorized as anti-poor.

The benefits of economic growth can be designed or implemented through fiscal decentralization policies. That is, fiscal decentralization has a strategic role to realize quality economic growth that leads to pro-poor growth. The next step is used the quadrant method to determine the regional distribution based on the pro poor growth results and the regional fiscal position based on transfer funds and capital expenditure.

\section{Findings}

East Java's economic growth reached $5.44 \%$ in 2015 , or better than the national growth of only $4.73 \%$ (BPS East Java, 2015). This condition is not in line with the welfare condition of the people of East Java. The number of poor people in East Java has increased by $0.06 \%$ in 2015 compared to 2014 (BPS East Java, 2015). The calculation result from the influence of local financial performance as measured using ratio of fiscal decentralization degree, ratio of local financial dependency, ratio of local financial independency, local income effectiveness, the growth of PAD, and the tax effort on economic growth and poverty level through capital expenditure shows different relations, directly or indirectly as shown in Figure 3.

\subsection{Degree of Fiscal Decentralization}

The degree of fiscal decentralization directly has a negative and significant effect on capital expenditure and poverty level, shows a positive and significant influence on economic growth, while indirectly it has a negative and significant effect on economic growth through capital expenditure, positive and significant on poverty level through capital expenditure, and shows a negative and significant influence on poverty level through economic growth. Some factors underlying the results of this study include fiscal improvement (PAD) which is not equal with the increase of capital expenditure allocation as discovered by Rusydi (2010). Furthermore, local authority in optimizing PAD is considered as capital. If accumulated, it will cause positive externalization and accelerate economic growth (Pujiati, 2008). However, as argued by Davoodi and Zou (1998), fiscal decentralization can have a negative impact on economic growth and poverty level because of: (1) excessive spending on the wrong expenditure post; (2) errors in the execution of duties of intergovernmental fiscal functions; (3) limitations by the central government on tax collection and spending decision; and (4) inadequate responses on the social needs from local governments. The findings by Slavinskaite (2016) showed that fiscal decentralization has a positive and significant effect on economic growth in EU-21 countries. These results indicate that local governments in highlevel developed contries (such as Sweden and Denmark) have greater power to control income and expenditure than those in low-level developed countries (such as Estonia and Poland). Another study by Yang (2016) found that the right level of decentralization helps to drive economic growth, but fiscal decentralization can hamper economic growth when it becomes too aggressive. 


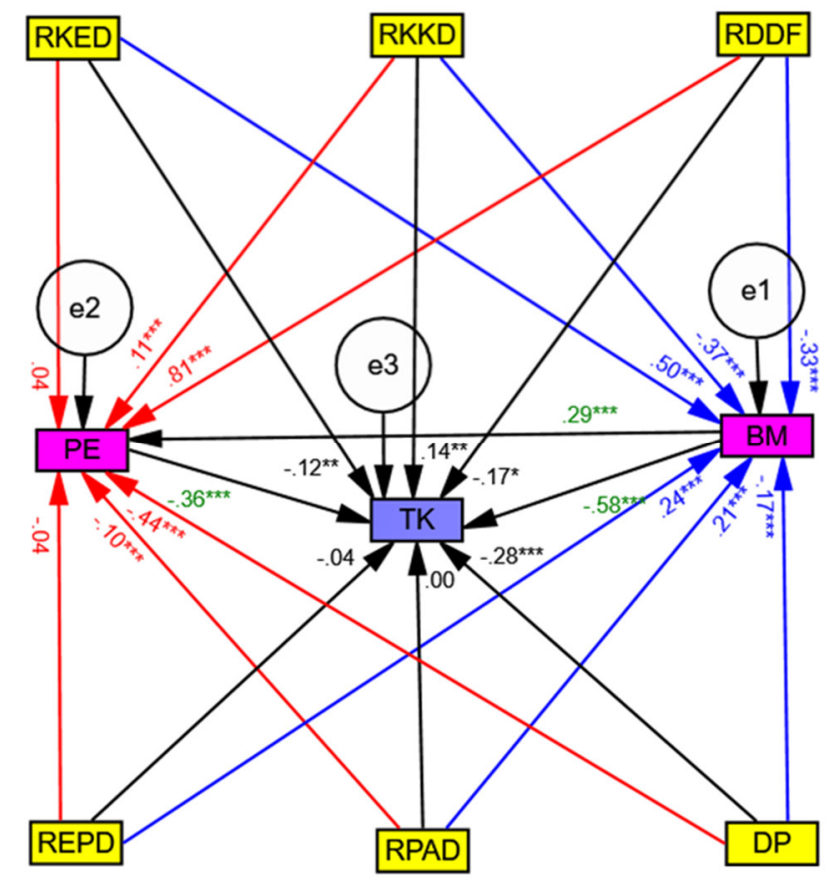

Figure 4. Direct and Indirect Influences of Local Financial Performance on Capital Expenditure, Economic Growth and Poverty

Source: Output IBM-AMOS 22, data processed 2018

Description: * Significant at $10 \%$ level

** Significant at 5\% level

$* * *$ Significant at $1 \%$ level

\subsection{Dependency of Local Finance}

The dependency on local finance directly has a negative and significant impact on capital expenditure and shows a positive and significant impact on economic growth and poverty level, while indirectly it has a negative and significant effect on economic growth and negative and significant effect on poverty level through capital expenditure, and shows no effect on the level of poverty through economic growth. Some of the underlying results in this study are: Firstly, the results of research by Legrenzi and Milas in Abdullah and Halim (2004) found that in the long period the transfer affects the capital expenditure and the reduction of the amount of transfer can lead to a decrease in capital expenditure. Secondly, the results of this study are in line with research conducted by Nanga in Lisna et.al (2013) which shows that fiscal transfer impacts on poverty and income inequality. The negative effect of fiscal transfer on poverty is supposed to appear due to ineffective distribution of fiscal transfer funds in the allocation of local expenditures. Thirdly, a research conducted by Arsa and Setiawina (2015) proved that financial dependency through capital expenditure allocation indirectly has a negative effect on economic growth. The main source of income for the local regions so far is the transfers from the central government. The transfers are DAU, DAK, DBH, and other types of transfers such as Local Infrastructure Development Fund. In this context, the budgetary policy taken by the local regions to improve the local economy and the social welfare will largely depend on their local strategies and priorities. The funds can be used by the region as set by the central government. This specific funding is expected to be a tool for local governments to influence local expenditure in achieving their goals, such as increasing economic growth and improving the societal welfare.

\subsection{Local Financial Independency}

The independency of local finance directly affects positively and significantly to capital expenditure, has no effect on economic growth, and shows a negative and significant influence on poverty level, while indirectly it has a positive and significant effect on economic growth and negative and significant effect on poverty level through capital expenditure, and shows no effect on poverty level through economic growth. Some of the underlying results in this study include: First, the findings in this study support the research by Sularso and Restianto (2011) which shows local independency has a significant effect on the allocation of capital expenditure. The more independent the local governments are, the more flexible they will spend their budgets on productive spending for their regions. Second, this research is in accordance with the theory put forward by Tiebout (1961), that is, a fiscal decentralization system in which the local government plays more important role than the central government in 
providing public services will drive economic growth. It shows that the local government is able to finance its own governmental activities, developments and services to the society. Third, the research by Ani and Dwirandra (2014) stated that the maximum management of PAD will be greatly useful to reduce poverty in the local regions. Negative relationship in the results of the study proves that the higher the local financial independency, the lower the poverty level. Independency describes the level of communal participation in local development; the higher the participation, the higher the funds available for capital expenditure. As stated by Halim in Sularso and Restianto (2011), the higher the ratio of independency, the more advanced the local development as well as the economic growth. Fourth, a positive relationship on the poverty level through capital expenditure indicates that in terms of budgetary planning, local governments tend to budget their local incomes in pessimistic ways (under estimate). The findings of this hypothesis are not in line with the consumption and investment theory which states that by investing and govermental spending through programs and activities it will bring benefits in the future and have an impact on the increasing of people's welfare. These results do not support the research conducted by Hamzah (2008) which stated that independency ratio has a positive effect on economic growth and economic growth negatively affects poverty.

\subsection{Local Income Effectiveness Ratio}

Local income effectiveness has a positive and significant influence on capital expenditure and has no influence on economic growth and poverty level, while indirectly it has a positive and significant effect on economic growth, and shows a negative and significant relationship to poverty level through capital expenditure, and no effect on poverty level through economic growth. Some of the underlying results in this study include: the efforts of local government to use and to realize the allocation of income maximally will impact on the increase of capital expenditure. It is possible because the determination of income target is still relatively low, especially from PAD (Suwandi and Tahar, 2015). The results of this study are in line with research conducted by Ani and Dwiandra (2014) who found no relation between income effectiveness and economic growth. It is because the realization of local governmental revenue compared to the target does not meet the principles of economical, efficient, and effective (value for money), especially from PAD, so it has less ability to encourage economic growth. Moreover, the study by Setyawan and Adi (2008) stated that high fiscal stress indicates the higher local effort to increase its income. In line with this, the hope to keep increasing the revenues will be difficult to realize if the expenditure allocation for capital or development is not increased.

\subsection{PAD Growth Ratio}

PAD growth directly has a positive and significant impact on capital expenditure, shows a negative and significant influence on economic growth, and no effect on poverty level, while indirectly it has a positive and significant effect on economic growth and negative and significant on poverty level through capital expenditure and shows no influence to poverty level through economic growth. The results supports the research conducted by Adi (2007) which stated that in local autonomy there has been an increase in local financial capacities in general, but the increase occurs due to a significant change in PAD growth. Furthermore, the research conducted by Kurnia (2013) and Kartikasari (2014) proved that local governments still greatly respond to their local expenditures from central government transfers that are unconditional in nature rather than from local revenues. Additionally it is also in line with the results of research conducted by Ani and Dwiandra (2015) who found that income growth has no significant effect on poverty. The situation is quite reasonable considering that with the increase in PAD, the local needs funded by the balance funds are more directed to operational and routine needs, such as personnel expenditure, goods/service expenditure and primary capital expenditure (education and health facilities). In turn, the portion of PAD will head to productive capital expenditure (spending on transportation facilities, and on supporting facilities for the trading sectors) and social assistance spending. It is in line with the research by Bappenas in Sularso and Restianto (2011) stating that PAD growth is sensitive to economic growth. It is supported by the results of a study by Nguyen and Anwar (2011) which found that the government of Vietnam collected local income very well, thereby giving contribution to economic growth.

\subsection{Tax Effort}

Tax efffort directly has a negative and significant impact on capital expenditure, economic growth, and poverty level, while indirectly it has no effect on economic growth through capital expenditure and shows a positive and significant influence on poverty level through capital expenditure and also through economic growth. The results of this study prove the agency theory through the relationship between the community and local government in terms of the collection of local taxes and levies wherein the level of public participation in local development, namely in paying taxes and levies is still low, so it has a negative relationship to capital expenditure. The revenue from local taxes is considered low compared to the targeted realization. On the other hand tax functions as a regulator, in this case local taxes can be used by local governments as an instrument to achieve goals. The imposition of local taxes can be done to influence the consumption level of certain goods and services so that it 
can inhibit people's purchasing power. On the other hand, based on empirical experience, if the local government receives a grant, it will be used to increase its spending without increasing taxes. The appearing deviation in the financial transfers of central government with the revenue or expenditure of local government is called the flypaper effect. These results support a research conducted by Lisna et. al (2013) which stated that the increase of fiscal capacities by upgrading local taxes of $20 \%$ results in reducing poverty and income inequality on poor agricultural households. As stated in a research conducted by Mourmouras and Rangazas (2009), in decentralization it is necessary to reform the high taxation and to reduce expenditure that does not lead to welfare because it can decrease local economic growth. Industrial sectors, notably services, need to be optimized. Taxes and levies are closely related to the activities of service in industrial sector, that is, the granting of tax authority as regulated in the Law of Local GDP is a tool for the regions to improve the competitiveness and economic growth which will finally reduce the level of poverty in the regions.

Overall, the most dominant financial performance affects capital expenditure, economic growth, and poverty levels is the degree of fiscal decentralization. Regional authority in optimizing PAD is considered as capital, accumulated more will cause positive externalization and will accelerate economic growth. That is, the local financial performance reflected by the PAD and the transfer fiscal (degree of decentralization and financial dependence) can affect economic growth, where the contribution of PAD is greater than the transfer fiscal to stimulate economic growth. Then, local financial performance can influence poverty reduction through the degree of decentralization, financial independence and tax effort, meaning that the effect of PAD's contribution has an impact on poverty reduction.

Developmental orientation and poverty in NSB shift from time to time. In the 1970s development was directed to growth with equity, that is poverty in a country should be aimed at equity. Then in the 1980s there was a shift in the development orientation; at that time poverty was aimed at welfare (in the broad sense). Next, in the 1990s the development orientation of the NSB changed into sustainable development. Meanwhile, at present (since the year of 2000s) the development orientation in NSB has been directed to pro-poor growth, that is a country's economic growth is aimed at efforts to alleviate poverty.

To realize the vision of East Java through three missions, it is conducted based on three general strategies, among others (RPJMD East Java 2009-2014 and 2015-2019): (1) Sustainable development focuses on people (people-centered development) inclusively, and prioritizes people participation (participatory-based development); (2) Pro-poor growth, which implicitly includes pro-poor, pro-job, pro-growth, and pro-environment strategies; and (3) gender mainstreaming (pro-gender).

The problems occurred in province of East Java start from the fact that its economic growth continues to increase and the percentage of poverty tends to decline, but the inequality of income distribution also increases. Therefore, it becomes the basis for evaluating whether economic growth has truly optimally impacted on poverty and income inequality. Through the measurement of PPGI, the results of this study prove the beneficial degree of economic growth processes.

Table 1. Pro Poor Growth Criteria in Regency and City of East Java Province, 2010 - 2015

\begin{tabular}{|l|l|}
\hline \multicolumn{1}{|c|}{ Criteria for Pro Poor Growth } & \multicolumn{1}{c|}{ Regency dan City } \\
\hline Anti pro poor $(\varnothing \leq 0)$ & Blitar City \\
\hline Weak pro poor $(0<\varnothing \leq 0,33)$ & - \\
\hline Moderate pro poor $(0.33<\varnothing \leq 0,66)$ & Reg. Situbondo; and Reg. Bangkalan \\
\hline \multirow{5}{*}{ Pro poor $(0,66<\varnothing \leq 1,0)$} & $\begin{array}{l}\text { Reg. Trenggalek; Reg. Malang; Reg. Jombang; } \\
\text { Reg. Madiun; Reg. Bojonegoro; Reg. Tuban; Reg. }\end{array}$ \\
& $\begin{array}{l}\text { Pamekasan; Reg. Sumenep; Probolinggo City; } \\
\text { Pasurusan City; Surabaya City and Batu City }\end{array}$ \\
\hline & $\begin{array}{l}\text { Reg. Pacitan; Reg. Ponorogo; Reg. Tulungagung; } \\
\text { Reg. Blitar; Reg. Kediri; Reg. Lumajang; Reg. }\end{array}$ \\
& $\begin{array}{l}\text { Jember; Reg. Banyuwangi; Reg. Bondowoso; Reg. } \\
\text { Strong pro poor }(1.0<\varnothing)\end{array}$ \\
& Probolinggo; Reg. Pasuruan; Reg. Sidoardjo; Reg. \\
& Mojokerto; Reg. Nganjuk; Kab.Magetan; Reg. \\
& Bojonegoro; Reg. Lamongan; Reg. Gresik; Reg. \\
& Sampang; Kediri City; Malang City; Mojokerto \\
& City; and Madiun City
\end{tabular}

Source: data processed, 2018

Simply it can be concluded that the growth occuring in the period of 2010-2015 in the districts and cities of

East Java tends to favor the poor. The reasons why growth is categorized as pro poor are as follows:

First, East Java still becomes one of the main drivers for the national economy with its relatively high share towards national economy reaching $14.64 \%$, the second-highest after DKI Jakarta of 17.19\% (2015).

Second, in terms of local finance, there is an increase in transfer funds to districts and cities, which is the 
largest revenue component (a reflection of the high fiscal dependency). In 2015, Surabaya reached the highest fiscal independency (57\%) and Sampang was the lowest $(6.9 \%)$.

Third, hotel and restaurant taxes are one of the components of PAD revenue driven by the high growth of accommodation and drinking-food sectors (e.g. City of Batu). On the other hand, Pasuruan Regency has the highest revenue realization during 2015 (reaching 109.7\%); it is the effort for improving the tax payment service for the society, and the scheme for giving reward to the sub-districts and villages that settle up the Land and Building Tax on time.

Fourth, in terms of expenditure, one of the main drivers of economic growth is the growth of Gross Fixed Capital Formation (PMTB) driven by the increasing realization of infrastructure projects of local government (the realization of infrastructure spending, especially water and road resources), some of which are the dam construction of Bajulmati and Nipah, and the toll road of Trans-Java e.g. the section of Mantingan-Kertosono, Kertosono-Mojokerto, Mojokerto-Surabaya, Southern Crossing, Gempol-Pandaan, Gempol-Pasuruan, PorongGempol, Pacitan-Malang and smelter in Tuban.

Fifth, in terms of societal welfare indicators, the increase of minimum wage in districts and cities was approved on November 2014. Of the 38 districts/cities, MSEs in Surabaya, Gresik, Sidoardjo, Pasuruan and Mojokerto are more than $\mathrm{Rp} 2.6$ million.

Sixth, The goverment proves its effort to increase the quality of workforce - it can be seen from the increasing amount of anually governmental budget in education (empirical data in 2012: primary school-graduated worker or below reaches $55.3 \%$, and university-graduated worker reaches $5.9 \%$, while in the year of 2015 primary schoolgraduated worker or below reaches $49.2 \%$, and university-graduated worker only $6.9 \%$ ).

Seventh, regional governments of East Java have several programs to eradicate poverty, such as empowering village/ward, facilitating MSME (UMKM) and Cooperative, establishing Integrated Licensing Service Center (P2T) to invite investors - The higher the investment, The higher the expectation to open new jobs that can employ a large number of people to reduce poverty.

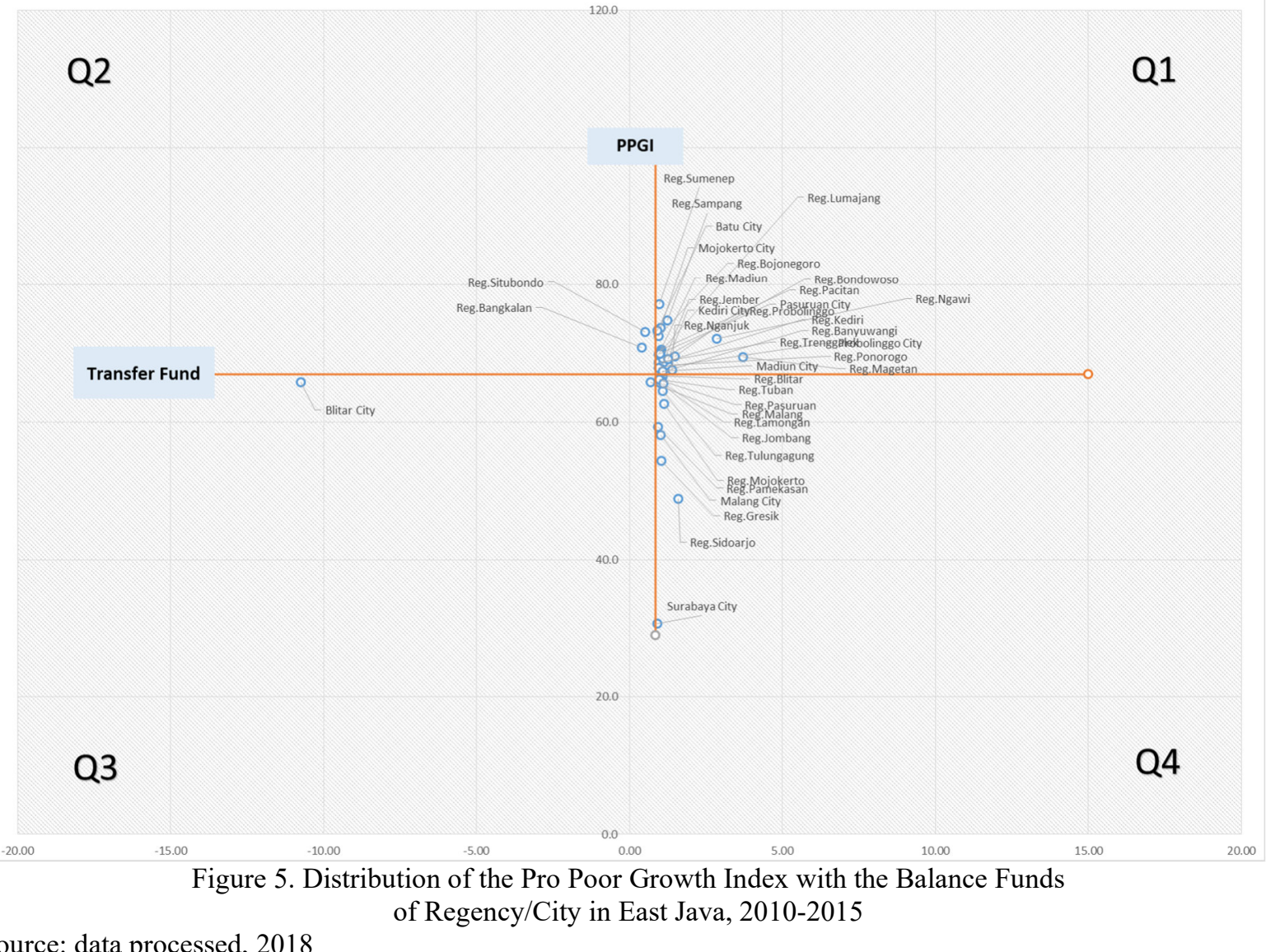

Source: data processed, 2018

Pro-poor budgets can be comprehended from the perspective of decentralization, viz. the budget for the poor at the local level. Decentralization basically teaches about the principle of bringing the state closer to the people; it gets the authority, governance, public service, and planning and budgeting closer from the state to the people, or from the national government to the regional ones. Sriningsih and Muadi Yasin (2009) revealed that fiscal decentralization is expected to improve the societal welfare through the implementatiton of inter-governmental 
revenue and expenditure for community. Thus, the pro poor growth of a region can be reflected on the implementation of fiscal decentralization through governmental revenue and expenditure.

Son and Kakwani (2004) showed that faster growth can slow down the poverty rate, or even increase it depending on how big the income inequality level increases. Not only high economic growth but also equal distribution of income is neccessary to accelerate the poverty reduction. As represented in the theory of modern economic growth, the increase in economic growth can be performed through policy design showing that economic growth is the impact of the strategic policy of economic development for societal welfare. Like in East Java, the benefits of economic growth can be designed or implemented through fiscal decentralization policies at the district and municipal levels which means fiscal decentralization has a strategic role to realize a qualified economic growth leading to pro poor growth.

From the aspect of income, the design of balance funds is essential to increase the qualified economic growth to beneficially improve the societal welfare. According Rochjadi (2006), fiscal decentralization is the local and national governments' instrument to create easiness in the implementation of regional development through the mechanism of better financial relation, so it attains better economic situation as the achievement of communal welfare.

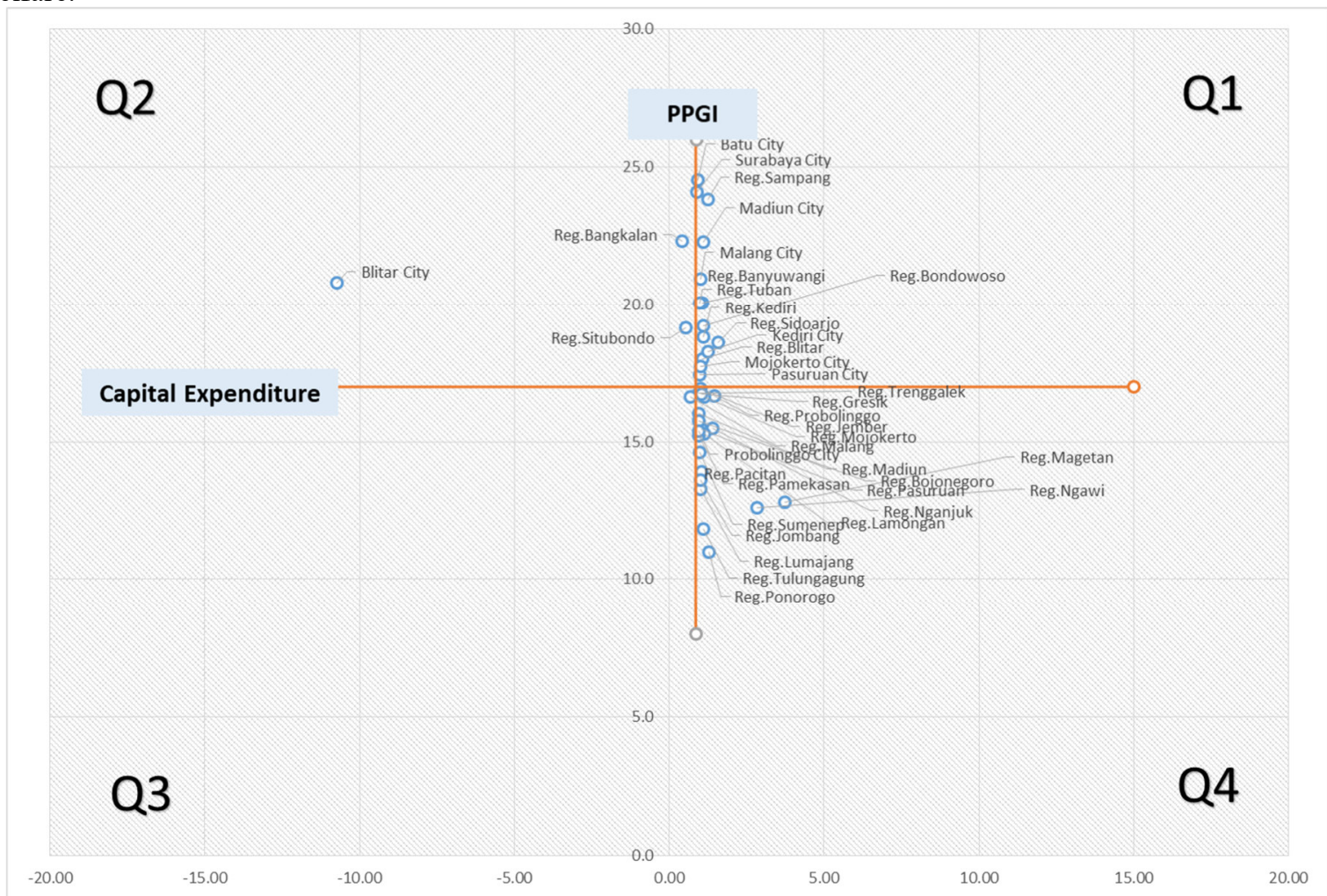

Figure 6. Distribution of Pro Poor Growth Index with the Capital Expenditures of Regency/City in East Java, 2010-2015

Source: data processed, 2018

District and municipal revenue is still dominated by balance funds from the central and provincial governments. Only Surabaya has PAD higher than the balance fund followed by Gresik and Sidoardjo which have PAD nearly close to balance fund. However, other districts and cities are still far from regional independency. The high fiscal transfers of DAU and the phenomenon of the flypaper effect lead to a notion of the importance to increasing fiscal capacity especially through local taxation revenues and profit sharing of taxation. This notion is grounded on the role of taxes in redistributing revenues through budgetary and regulatory functions. Thus, the use of the fiscal capacity funds is allocated more on strategic regional spending to alleviate poverty.

From the aspect of expenditure, the implementation of fiscal decentralization can be depicted on the necessitybased expenditure wherein it gets increasing every year in the districts and cities. The top five spending sequences are educational spending, general-governance expenditure, health spending, public-works expenditure, and agricultural expenditure. It demonstrates the local governments' commitment towards necessities or sectors directly related to the communal welfare from the expenditure aspect. Hence, it can be argued that public investments in this case education, health, and infrastructure are proved to reduce poverty which affect the pro poor growth.

Nevertheless, the financial management problems on districts/municipalities in East Java in the era of fiscal 
decentralization still occur particularly in terms of regional expenditures, i.e. most regions of East Java still allocate capital expenditure in smaller portion than the allocation of personnel expenditure. As a consequence, A fundamental change on APBD structure is needed to enlarge fiscal opportunity. It is necessary to reformulate the budgetary policy, so the use of fiscal decentralization can improve the people's welfare and stimulate regional economic growth. APBD should be able to stimulate the economy through the composition of governmental spending which is spent more for the less productive posts so far. Thus, the implementation of regional financial performance and governmental spending is supposed to optimize economic growth and to reduce poverty.

Public investment expenditures in rural areas for instance infrastructure investment, agricultural investment, and educational investment affect on the reduction of the poor (Fan, 2004). Meanwhile, Suparno (2010) revealed that the increase in realization of APBD expenditure will work up the governmental capability, especially local governments in terms of funding to overcome poverty.

The correlation between the regional budget and regional development is quite high. This is due to increasing regional development requires costs reflected in the budget. Like the exposure based on quadrants, there are 14 districts / cities that have high capital expenditure (above the provincial average) and there are 13 districts/ cities that have a low level of financial dependence (below the provincial average). If it is concluded from the two distributions in the above quadrant, that Surabaya City, Blitar Regency, Tuban Regency, and Sidoarjo Regency can be used as examples of areas that have been able to optimize the extraction of regional revenues (proven by low dependency levels), then able to spend towards development spending (proven by capital expenditure above the provincial average), and efforts to improve economic growth, reduce poverty and reduce inequality of income distribution (pro poor growth).

The policy of pro poor growth is a policy that promotes economic growth resulting in the reduction of poverty and income inequality. However, not all economic growth has the same effects. According to Meier (1995), the causes are: (1) low economic growth rate; (2) unbalanced economic growth patterns; and (3) failure on governmental policy. Pro poor growth strategy can be performed through fiscal policy by increasing national and local taxes to raise regional fiscal revenue which finally affects on local expenditure augmentation. Furthermore, the increase in local expenditures augments the regional output directly and the individual income indirectly, so it will raise public consumption. The policy of fiscal decentralization is carried out by applicating policies on wider authority of income and expenditure, but the afore-mentioned policies will emerge trade-off among economic growth, poverty and income inequality due to the high financial dependency of local governments to the central government.

Based on the explanation above, it can be concluded that pro poor growth can be an important concept to detect patterns of economic growth, poverty and inequality, whereas fiscal decentralization is a form of government intervention to encourage economic growth, and to reduce poverty and societal imbalance. Both of these concepts show that they can provide implications or recommendations on developmental strategies or policies, especially at the regional/municipal level.

\section{Conclusion}

The results of the analysis indicate that one of the factors that influence economic growth and poverty level is the local financial performance with the degree of fiscal decentralization as the dominant variable. Performance contributions from the PAD side are greater than the transfer fiscal to stimulate economic growth and poverty reduction. That is, regional development financing to accelerate economic growth and alleviate poverty is more dependent on fiscal capacity derived from PAD (taxes, retribution, BUMD profits, revolving funds, etc.) rather than fiscal transfers (DAU, DAK, and DBH). Then, the study show that economic growth in regencies and cities is generally classified as pro poor growth (both in path analysis and PPGI) with the main driving factors are increased realization of regional infrastructure projects, increased regional revenues from taxes and fiscal transfers, and increased spending on affairs such as education, health, and public works. There are 35 regions that have been classified as pro-poor, while 3 regions namely Blitar City, Situbondo Regency, and Bangkalan Regency are regions that are classified as anti-pro poor and moderate pro-poor.

Finally, from the conclusions above, it can be derived some suggestions: First, because of the dominant role of the degree of decentralization (PAD), it is necessary to intensify and extend regional revenues (taxes, retributions, and the role of BUMD), for example through tax devolution, expansion of the tax base (identification of new / potential taxpayers and improving the database object of tax), simplification of tax administration, and selection of the right BUMD area for consideration of formation. However, these efforts must prioritize appropriate public policies for each region to minimize market failures (eg local regulations which form the basis for collecting taxes and levies in order to achieve the PAD target does not become a burden for productive economic actors, especially for investors). Second, the government must make planning and budget priorities that favor the provision of quality public facilities, through productive capital expenditure (networks, irrigation, roads, etc.) and focus on sectors that are the basis of the economy of each region (for example: the City of Surabaya and the City Batu in the trade, hotel and restaurant business sector. Third, there are clear limits to the structure of regional 
budgets to minimize waste on posts that are less productive to optimize the allocation of regional budgets and in order to realize optimal budget absorption performance. Then, efforts to improve pro poor growth through government policies must continue to be carried out which are implemented into strategic development programs in each region through wise planning and budgeting, timely implementation of programs and activities (implications for absorption budget), monitoring and evaluation of programs and activities that are seen as benefits for sustainability. And so that local governments can be balanced in paying attention to aspects of economic growth (pro growth) and also equity (pro poor). Where this can be done through a fiscal decentralization scheme, revenues are directed at efforts to increase PAD rather than fiscal transfers and spending is directed at capital expenditures rather than government administration and employees (and there are limits to the use of budget with a clear percentage).

\section{References}

Abdullah, Syukriy, and Abdul Halim. 2004. Effect of General Allocation Funds (DAU) and Regional Original Revenues (PAD) on Regional Government Expenditures. National Accounting Symposium VI, page. 11401159

Adi, Priyo Hari. 2005. Regional Financial Capabilities in the Era of Autonomy and Relevance with Economic Growth (Studies in Districts and Cities in Java - Bali). The 1st Accounting Conference Accounting Department, Faculty of Economics, University of Indonesia

Ani, Ni Luh and Dwiandra. 2014. Effects of Regional Financial Performance on District and City Economic Growth, Unemployment and Poverty. E-Juornal Accounting at Udayana University 6.3: 481-497

Arsa, I Ketut and Nyoman Djinar Setiawina. 2015. Effect of Financial Performance on Allocation of Capital Expenditures and Economic Growth of Regency / City Governments in Bali Province in 2006 - 2013. Journal of the Economic Study Bulletin, Vol. 20 No. 2, August 2015

Bourguignon, F. 2004. The Poverty-Growth-Inequality Triangle. World Bank. New York: Mimeo

Central Bureau of Statistics. 2016. Bank Indonesia Regional Study. jatim.bps.go.id

Davoodi, H., \& Zou, Heng-Fu. (1998). Fiscal Decentralization and Economic Growth : A Cross-Country Study. Journal of Urban Econoics, 43:244-57.

Fan, S., Huong, P.L., \& Long, T.Q. (2004).Government Spending and Poverty Redu-ction In Vietnam. Project report preparedfor the World Bank funded project pro-poor spending in Vietnam. Washington, D.C.: International Food Policy Research Instituteand Central Institute for Economic Management.

Farwati, R. 2012. Pro-Poor Growth: Does it Work in Indonesia?.Thesis. Netherland: The Hague.

Halim, Abdul. 2008. Investment Analysis (Capital Expenditures) of the Regional Government Public Sector. Yogyakarta: UPP STIM YKPN.

Hamzah, Ardi. 2008. Financial Performance Analysis of Economic Growth, Unemployment and poverty: Path Analysis Approach (Study in 29 Regencies and 9 Cities in East Java Province 2001-2006 Period)Kakwani, N \& Pernia E.M. 2000. What is Pro-Poor Growth? Asian Development Review. Vol 18 No. 1.

Kakwani, Nanak and Hyun H. Son. 2008. Poverty Equivalent Growth Rate. Review of Income and Wealth Series 54, Number 4

Krongkaew, M, \& Kakwani, N. (2003). The Growthequity Trade-Off in Modern Economic Development: The Case of Thailand. Journal of Asian Economics, 14(5), 735-757

Kuncoro, M. 2006. Development Economics: Theory, Problems and Policies. Yogyakarta: UPP STIM YKPN.

Lisna, Vera et. al. 2013. Impact of Fiscal Capacity on Reducing Poverty: A Policy Simulation Analysis. Indonesian Journal of Economics and Development Vol. 14 No. 1, Juli 2013: 1-26 ISSN 1411-5212

Mahmudi, 2010. Analysis of Local Government Financial Reports. Second Edition. Publisher UPP STIM YKPN, Yogyakarta

Meier, G. M. (1995). Leading Issues in EconomieDevelopment, 6th ed. New York: Oxford University Press.

Mourmouraz, Alexandros dan Peter Rangazaz. 2009. Fiscal Policy and Economic Development. Macroeconomic Dynamics, 13 (2009), 450-476

Nguyen, Lan Phi dan Sajid Anwar. 2011. Fiscal Decentralisation and Economic growth in Vietnam. Journal of the Asia Pacific Economy Vol. 16, No. 1, February 2011, 3-14

Piotrowska, Maria. 2016. The Direct and Indirect Effects of The Pro-Poor Growth. Bulletin of Monetary Economics and Banking, Volume 18, Nomor 3

Pujiati, Amin. 2008. Economic Growth Analysis in Semarang Residency Era of Fiscal Decentralization. Economic Development Journal of the Economics of Developing Countries, page: 61-70

Qiao, Baouyun, et.al. 2008. The Tradeoff Between Growth and Equity in Decentralization Policy: China's Experience. Journal of Development Economics 86 (2008) 112-128

Rusydi, Bahrul Ulum. 2015. Analysis of Determinants of Local Government Financial Performance and Detection of Fiscal Illusions (Case Study of Provinces in Indonesia in 2005-2008). Iqtisaduna, Volume 1 Number 2 , December 2015: 116-129 
Slavinskaite, Neringa. 2017. Fiscal Decentralization and Economic Growth in Selected European Countries. Journal of Business Economics and Management Volume 18 (4): 745-757

Sriningsih and Muadi Yasin. 2009. Impact of the General Allocation Fund (Dau) on District / City Fiscal Equity in West Nusa Tenggara. Year Economic Magazine XIX, No. 2 August2009

Sularso, Havid and Yanuar E. Restianto.2010. Effect of Financial Performance on the Allocation of Capital Expenditures and Regency / City Economic Growth in Central Java

Suwandi, Kurni Adi and Afrizal Tahar. 2015. The Influence of Financial Performance on Regional Economic Growth with Allocation of Capital Expenditures as Intervening Variables (Study on Regency/City Government D.I. Yogyakarta). InFestasi Journal Vol. 11, No.2, December 2015, page.118-136

Yang, Zhou. 2016. Tax Reform, fiscal Decentralization, and Local Economic Growth: New Evidence from China. Journal Elsevier Economic Modelling 59, 520-528

Zhang, T. dan Zou, H. 1998. Fiscal Decentralization, Public Spending, and Economic Growth in China. Journal of Public Economics, LXVII: 221 